\title{
BIOEDUSCIENCE
}

ISSN: 2614-1558

\section{Distribution of Anisakidae Family infected Marine Fish from Indonesia}

\author{
Putri Desi Wulan Sari'1, Sri Subekti', Yarin Dwi Monica1
}

${ }^{1}$ Program Studi Akuakultur, Fakultas Perikanan dan Kelautan, Universitas Airlangga, Kampus C - Mulyorejo, Surabaya, Indonesia 60115

*Correspondent Email: putri.dw@fpk.unair.ac.id

\section{ARTICLE INFO}

\section{Article history}

Received: 21 Jan 2021

Accepted: 22 Jun 2021

Published: 31 Dec 2021

\section{Keywords:}

Anisakidae;

Distribution;

Environment;

Indonesia marine fish;

\section{A B S T R A C T}

Background: Family of Anisakidae is one of the zoonotic helminth parasitics. The distribution of the family Anisakidae is extensive. It needs to be known because the diversity of parasites can provide information about the distribution area and impact of the parasites of the family Anisakidae in Indonesia. This review article summarises the distribution of parasites from the family Anisakidae that infects marine fish and the factors that influence Indonesia. Methods: This research is qualitative research through literature study as the main object. The data from the literature study results are presented in tables and figures then explained descriptively. Results: The distribution of Anisakidae in Indonesia is found in four genera, namely the genus Anisakis, Pseudoterranova, Terranova and Contracaecum, which are mostly found from the carnivorous marine fish of the family Balistidae, Carangidae, Epinephelidae, Lutjanidae, Priacanthidae, and Scombridae Conclusions: Four genera of endoparasitic worms from the Anisakidae family were reported to infect Indonesian marine fish, including Anisakis, Pseudoterranova, Terranova and Contracaecum. Temperature, salinity, hosts' presence, and anthropogenic factors are biotic and abiotic factors that can affect the distribution of Anisakidae. The information on this literature study results is hoped to develop research in fish parasitology in particular and increase public awareness of fish processing in general.

\section{Sebaran Parasit Cacing Anisakidae Pada Ikan Laut di Indonesia.}

\section{A B S T R A K}

Background: Famili Anisakidae merupakan cacing parasit pada ikan yang bersifat zoonosis atau dapat menginfeksi manusia yang mengkonsumsinya. Distribusi dari famili Anisakidae sangat luas dan pemetaan terhadap area persebaran diperlukan untuk memberikan informasi mengenai genus yang menginfeksi pada ikan beserta area persebarannya. Review artikel ini dibuat untuk merangkum persebaran genus parasit dari famili Anisakidae yang menginfeksi ikan laut dan faktor pendukung terjadinya infeksi di wilayah Indonesia. Metode: Penelitian ini menggunakan metode kualitatif melalui studi literatur dengan memanfaatkan literatur-literatur sebagai objek utama dan data dari hasil studi literatur disajikan dalam bentuk tabel kemudian di jelaskan secara deskriptif. Hasil: Terdapat empat genus cacing famili Anisakidae yang menginfeksi ikan laut di Indonesia, yaitu genus Anisakis, Pseudoterranova, Terranova dan Contracaecum, yang rata-rata ditemukan pada golongan ikan laut karnivora dari famili Balistidae, Carangidae, Epinephelidae, Lutjanidae, Priacanthidae dan Scombridae. Kesimpulan: Empat genus cacing endoparasit dari family Anisakidae dilaporkan menginfeksi ikan laut Indonesia, antara lain Anisakis, Pseudoterranova, Terranova and Contracaecum. Suhu, salinitas, keberadaan hospes dan faktor antropogenik merupakan faktor biotik dan abiotik yang dapat mempengaruhi persebaran Anisakidae. Melalui informasi pada hasil studi literatur ini, diharapkan dapat menjadi dasar pengembangan penelitian bidang parasitologi ikan khususnya dan peningkatan kewaspadaan masyarakat terhadap pengolahan ikan pada umumnya.

(C) 2021 by authors. License BIOEDUSCIENCE. UHAMKA, Jakarta. This article is open access distributed under the terms and conditions of a Creative Commons Attribution (CC-BY) license. 


\section{Introduction}

Family Anisakidae is one of the parasitic worms in fish that can be zoonotic or infect humans, the cause of the onset of anisakiasis disease (Liananda et al., 2017; Sohn et al., 2014). Anisakiasis has been reported in Japan since 1993 as a result of consuming raw fish such as "sushi/sashimi" infected by Anisakis worms and Pseudoterranova (Ishikura et al., 1993; Yorimitsu et al., 2013; Murata et al., 2018). Various genera of the family Anisakidae have been reported to infect fish, including Anisakis, Pseudotteranova, Terranova, Contracaecum and Phocascaris (Smith \& Wootten, 1978; Zając et al., 2015; Aibinu et al., 2019). The parasite belongs to worm parasites that have the primary host of aquatic mammals such as whales, dolphins and seals, while fish can be intermediate or intermediate hosts (Measures, 2014).

In addition to biotic factors, the distribution of a species can also be influenced by abiotic factors. Biotic factors can affect the issuance of a species through predation, parasitism, competition, and disease that limit the distribution of other species. At the same time, abiotic factors come from nonliving things such as temperature, climate, salinity, and others. These factors can affect the area of distribution of an organism in a place or region. The importance of knowing the issuance of an organism is to know its characteristics, morphology, type and abundance (Campbell, 2010).

Indonesia produces the most significant fishery resource products through marine catches (Ministry of Marine Affairs and Fisheries, 2018). Indonesia's strategic position flanked by the Pacific Ocean, Indian Ocean and between Asia and Australia forms an 81,000 km coastline and is the longest coastline in the world. The vastness of the marine area creates Indonesia's advantage in producing fishery and marine resources. It gives rise to varying environmental conditions so that it can be possible to occur differences in the diversity of anisakidae family worms in the Indonesian aquatic environment. Diba (2009) revealed that one of the factors of infection of the family worm Anisakidae in fish could be due to the environmental conditions of the waters.

This literature study aims to find out the parasitic worms of the anisakidae family that infects marine fish in Indonesia and knows the distribution area. It can be used as a reference in mapping worm parasites in fish. This is an effort to develop research in fish parasitology and increase public awareness of fish processing as food.

\section{Methods}

The method used in literary studies is the qualitative method. Literature on the spread of Anisakidae worms in marine fish in Indonesia is used as the main object. Data collection is collected by being searched, selected, presented and analyzed, and developed and processed into a simple framework. The data obtained will be examined and selected based on its truth before being presented in information (Mantra, 2008). Data from literature studies were presented in table form, explained descriptively, narratively, concisely, and systematically.

This research uses data analysis in the form of descriptive analysis and content analysis. Descriptive analysis is done by displaying images and captions objectively, systematically, and analytically, while content analysis is done by processing information scientifically about the contents of a data message. Literature data obtained from electronic databases include textbooks, scientific articles in nationally accredited and unaccredited journals. Keywords used in the search for this literature study include the spread of Anisakidae in Indonesia, cases of Anisakidae in Indonesia, Anisakidae, Anisakis, Pseudoterranova, Contracaecum, Terranova, Anisakidae in humans.

\section{Results}

\section{Anisakidae distribution in Indonesia}

Anisakidae is a family of nematode worms that are zoonotic and can infest a variety of aquatic biota during the development of their larvae, including marine mammals, pelicans, cephalopods, renic shrimp and sea fish. (ÁngelesHernández et al., 2020; Guan et al., 2021). The dominant predilection of Anisakidae is in the viscera body cavity of the host and is minorly in the muscles of fish (Piras et al., 2014). The family Anisakidae is a worm with a wide distribution globally, including in Indonesia and can be found in the waters of tropical and subtropical countries (Mattiucci \& Nascetti, 2006).

\section{Genus Anisakis}

Genus Anisakis is one of the many reported genera of the family Anisakidae in the world. Nine species of Anisakis have been reported to infect various species of fish, namely A. simplex, A. pegreffii, A. berlandi, A. typica, A. ziphidarum, A. nascettii, A. paggiae, A. physeteris, and A. brevispiculata. Other types of anisakis such as A. ziphidarum, A. Nascettii and $A$. brevispiculata are found in marine mammals such as whales (Mattiucci et al., 2014). Anisakis has a characteristic larva coloured beige, on the anterior, there is a dull tooth, ventriculus appears elongated and like black spots (which characterize Anisakis), and excretory channels in the posterior (Pradipta et al., 2015). In Indonesia there have been reported infections of Anisakis simplex, Anisakis typica and Anisakis physeteris spread in several of the water of Indonesian territory and infect some fish consumption at the auction and landing of fish (Table 1). According to Pekmezci et al. (2014), Anisakis typica is a species that has a wide distribution area of tropical and subtropical regions but is more dominant in the tropics. 
Table 1. Anisakidae distribution in Indonesia




In Indonesia, Anisakis typica has been widely reported in eastern areas of Indonesia, such as in the Makassar Strait, West Sulawesi, Bali, Papua and for western areas of Indonesia reported from the southern waters of Java and Banten Bay (Table 1). Anisakis simplex is widely reported to infect marine fish in areas with temperate climates, more commonly found in the Atlantic and Pacific Oceans and in waters west of the Mediterranean (Mattiucci \& Nascetti, 2006). In Indonesia, Anisakis simplex can be found in several regions such as java, North Sumatra, Makassar and Kupang. Anisakis physeteris infection has been reported in the sea fish Mugil curema in the waters of Tumaco, Colombia (Castellanos et al., 2020); Tuna (Scombridae) from a catch in Rio de Janeiro, Brazil (Knoff et al., 2017). In Indonesia, Anisakis physeteris infection was reported through Puspitarini et al. (2018) research in red snapper obtained from Lampung waters in Indonesia

\section{Genus Pseudoterranova}

Genus Pseudoterranova is a parasite that can infect fish from the family Anisakidae, which is also found in humans. The genus Pseudoterranova comes from the family Anisakidae, is a parasite that can infect fish and can also be found in humans (Brunet et al., 2017). Morphological features including brown or red, have larval teeth, intestinal caecum protruding next to the esophagus, posterior part of the body tapered off, body length more than $11 \mathrm{~mm}$, width $25 \mu \mathrm{m}$ has teeth with a length of $12 \mu \mathrm{m}$ in anterior and anus and mucosa in the posterior (Aline et al., 2017).



Figure 1. Larvae (L3) Pseudoterranova. A: The anterior part. BT. boring tooth, P. papillae, TA. Transverse annulation. B: The posterior part. TA. Transverse annulation. AN. Anus. MU. Mucron C: Mucron (Quraishy et al., 2019).

In the world of pseudoterranova genera that have been reported to infect marine and human fish, namely from the species P. decipiens, P. cattani and P. azarasi (Hossen \& Shamsi, 2019; Weitzel et al., 2015; Arizono et al., 2011). In Indonesia the presence of new Pseudoterranova is reported in demersal fish such as grouper fish (Epinephelus coioides) and red snapper (Lutjanus malabaricus) found in the waters of East Java (Alim, 2018; Rahmi, 2020).

\section{Genus Contracaecum}

Parasites of the genus Contracaecum macroscopically have a reddish-brown body, have a boring tooth, intestinal caecum protruding beside the oesophagus, posterior part of the worm's body tapered off, and mucron does not develop properly (Rodríguez et al., 2020). The genus Contracaecum belongs to the family Anisakidae, which infects marine and freshwater biota, including fish and land animals. Contracaecum species that have been reported in the world there are 142 species. Contracaecum osculatum is one of the genus Contracaecum that has been reported to infect cod (Buchmann \& Mehrdana, 2016). The genus Contracaecum has a reasonably wide distribution and can infect seawater fish and freshwater fish. The spread of Contracaecum in Indonesia has only been reported in red snapper (Lutjanus malabaricus) in the waters of East Java (Rahmi, 2020).

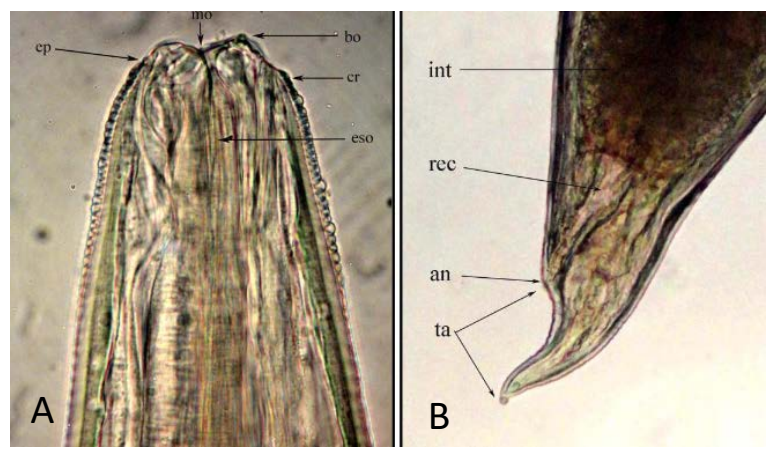

Figure 2. Larva Contracaecum, A: anterior. B: posterior (Abdullah et al., 2021)

\section{Genus Terranova}

Leiper and Atkinson first reported the genus Terranova in 1941 in the subclass Elasmobranchii. These parasites can be found in the visceral cavity and can form capsules in organs such as the liver, stomach and visceral cavity walls. The morphology of Terranova has a yellowish-white colour, has ventriculus and oesophagus (Gunarto, 2006). Unlike other genera, the genus Terranova in Indonesia has been reported new from the family fish Epinephelidae such as Grouper Fish (Epinephelus sp.) found in the waters of East Java (Handayani, 2019 and Alim, 2018).

Anisakidae family worms in Indonesia are widely reported to come from areas with extensive fishing industry and infect economically important fish species. The species of fish that this parasite can infect are the average of predatory fish. Parasites from the family Anisakidae are worm parasites that can be zoonotic or can infect humans if eating fish infected with Anisakidae worms in raw or undercooked conditions (Liananda et al., 2017; Sohn et al., 2014). The genus Anisakis can cause Anisakiasis, while the genus Pseudoterranova can cause pseudoterranovosis in humans, with clinical symptoms. Such as allergies, nausea, vomiting, pain and diarrhoea 
(Ivanovic et al., 2017; Pozio, 2013; Bucci et al., 2013; Hutama et al., 2018).

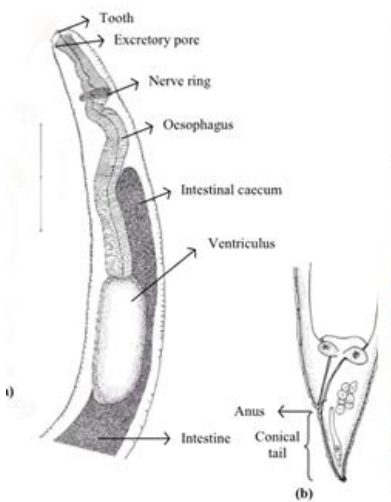

A

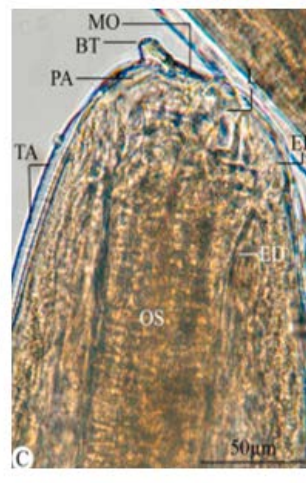

B
Figure 3. Terranova larvae. A. Terranova images using a Lucida camera. a. Anterior part. b. Posterior (Shamsi \& Suthar, 2016). B. Photomicrograph anterior larva Terranova (Hoshani et al., 2020)

Other Anisakidae families, including Contracaecum and Terranova, are also zoonotic worms that cause health problems for humans and cause a decrease in the selling value of infected fish. Excretion and secretion of allergic substances from Anisakidae worms and the ability of larvae to move into the muscular system and interfere with the immune system is one form of pathogenicity of Anisakidae worms to watch out for (Lima et al., 2019; Mehrdana \& Buchmann, 2017).

\section{Distribution Factors "Parasite Family Anisakidae"}

In his research, Khun et al. (2016) stated that both biotic and abiotic factors could influence the distribution of a species. For biotic factors of the existence and migratory behaviour of aquatic mammals such as dolphins or whales that are the main host of the family Anisakidae (Baladin, 2007), transmission and interrelationship between parasites and definitive host, intermediate or intermediate host and behaviour migration of each species (Baird et al., 2014; Buchmann \& Mehrdana, 2016). Water temperature as one of the abiotic factors, according to Mattiucci \& Nascetti, (2006), can affect the distribution of Anisakis. The presence of changes in temperature and polluting substances can change the salinity of the waters, causing the condition of the seas not to support the life of fish. Aquatic conditions that do not help fish life can cause fish to become stressed and cause some fish species to be susceptible to parasitic infections (Tafonao, 2011).

It is known that more than 30 species of aquatic mammals migrate through Indonesian waters, with the largest migration area being in eastern Indonesian waters. The waters of Lamarela and the Makassar Strait are considered one of the marine mammals' migration routes (Yusron, 2012). The presence of anisakidae infection in marine mammals in the Makassar strait indicates that the waters act as a habitat for Anisakis, which then infects several types of marine fish from the Makassar Strait (Anshary, 2014). Indonesian waters have a striking character difference in the western and eastern regions. The Java Sea, Sunda Strait, Natuna Sea, Malacca Strait and Makassar Strait are sea zones in west Indonesia with shallow topography with an average sea depth of fewer than $200 \mathrm{~m}$.

In comparison, eastern Indonesian waters such as the Flores Sea and Banda Sea are deep-sea zones whose sea depth can reach more than $2000 \mathrm{~m}$ (Kushadiwijayanto et al., 2019). The existence of differences in the character of these waters cannot be used as a specific determining factor in the distribution of Anisakidae. They were considering that species of marine fish infected with Anisakidae are very diverse and come from various habitats, and the discovery of various aquatic biota infected with adult and larval Anisakidae (Bilska et al., 2015; Kuhn et al., 2016; Ángeles-Hernández et al., 2020; Siagian and Maryanti, 2020). However, through research conducted by Guan et al. (2021), the temperature has a significant role in influencing the movement of larvae of Anisakis and Pseudoterranova. It is also supported by research conducted by Cipriani et al., 2016 and Łopieńska-Biernat et al., (2019). In addition to temperature, salinity, the presence of hoaxes, and anthropogenic factors are water parameters that can affect the successful development of larvae and the distribution of the Anisakidae family in the waters (Bilska et al., 2015; Siagian \& Maryanti, 2020; Raharjo et al., 2018).

The Java Sea is a fishing area in Indonesia with many productions (Meirinawati \& Iskandar, 2019). Many fish have been infected with the parasitic worm Anisakidae from these waters. The waters of the Java Sea and parts of the sea in Indonesia are affected by the Munson system, which results in the transfer of water mass from the South China Sea with cold temperature and low salinity character. The Java Sea has a salinity character with a 31-34 ppt, and the lowest value of salinity occurs in May, while the highest value of salinity occurs in September. In the Eastern season (June-July), surface salinity tends to be higher than during the Western season (December-February), and the surface temperature of the Java Sea ranges from $25.74-35.00^{\circ} \mathrm{C}$ with an average value of $31.37^{\circ} \mathrm{C}$ (Susilo et al., 2015). Water temperature can also affect the speed of egg development of Anisakidae with a maximum temperature of $13^{\circ}-20^{\circ} \mathrm{C}$ (Vega et al., 2017), while according to Khun et al. (2016), the salinity factor of water does not significantly affect the development of Anisakidae eggs.

\section{Conclusion}

Four genera of endoparasitic worms from the family Anisakidae reportedly infect Indonesian marine fish, including Anisakis, Pseudoterranova, Terranova and Contracaecum. Temperature, salinity, hoaxes, and 
anthropogenic factors are biotic and abiotic factors that can affect the spread of Anisakidae.

\section{Declaration statement}

The authors reported no potential conflict of interest.

\section{References}

Abdullah, Y.S. S.M.A. Abdullah, R.H. Hussein. 2021. Morphology and molecular studies of Contracaecum larvae (Nematoda : Anisakidae) in some fish species from Sulaimani Province, Kurdistan Region, Iraq. Basrah Journal of Agricultural Sciences, Vol. 34 (10) : 93-110.

Aibinu, I.E., Smooker, P.M. and Lopata, A.L. 2019. Anisakis nematodes in fish and shellfish-from infection to allergies. International Journal for Parasitology, Vol. 9: 384-393.

Alim, Y.R.R. 2018. Scanning Electron Microscope (SEM) Morfologi Anisakidae pada Ikan Kerapu dari Laut Pacitan. Thesis. Fakultas Kedokteran Hewan. Universitas Airlangga. 42 hal.

Aline, M.D.S.S., Marcelo, K., Felizardo, N., Sergio, C. 2017. Nematode and Cestode Larvae of Hygienic-Sanitary Importance in Lopholatilus villarii (Actinopterygii) in the State of Rio de Janeiro, Brazil. Boletim do Instituto de Pesca, São Paulo, Vol. 43(3): 358-398.

Ángeles-Hernández, J.C., Anda, F.R.G., Reyes-Rodríguez, N.E., VegaSánchez, V., García-Reyna, R.B., Campos-Montiel, R.G., Calderón-Apodaca, N.L., Salgado-Miranda, C., ZepedaVelázquez, A.P. 2020. Genera and species of The Anisakidae family and their geographical distribution. Animals, Vol. 10 : 2374.

Anshary, H., Sriwulan, M. A. Freeman. Ogawa, K. 2014. Occurance and Molecular Identification of Anisakis, Dujardin, 1845, from Marine Fish in Southern Makassar Strait, Indonesia. Korean Journal Parasitolology, Vol. 52(1): 9-19.

Arizono, N, Miura, T., Yamada, M., Tegoshi, T., Onishi, K. 2011. Human infection with Pseudoterranova azarasi roundworm. Emerging Infectious Diseases, Vol. 17: 555-556.

Ayun, N.W., Dewi, L.S., Murwantoko, Setyobudi, E. 2021. The occurance of Anisakis larvae on haritail, Trichiurus lepturus caught from the Pangandaran Waters, West Java, Indonesia. Biodiversitas, Vol. 22(3) : 1378 - 1384.

Baird, F. J., Gasser, R. B., Jabbar, A., Lopata, A. L. 2014. Foodborne anisakiasis and allergy. Molecular and Cellular Probes, Vol. 28(4): 167-174.

Baladin, L. 0. 2007. Studi Ketahanan Hidup Larva Anisakidae dengan Suhu Pembekuan dan Penggaraman pada Ikan Kembung (Rastrelliger spp.). Bogor: Pascasarjana Istitut Pertanian Bogor, 55 hal.

Bilska-Zajac, E., Różycki, M., Chmurzyńska, E., Karamon, J., Sroka, J., Kochanowski, M., Paweł Kusyk, P., Cencek, T. 2015. Parasites of Anisakidae Family - Geographical Distribution and Threat to Human Health. Journal of Agricultural Science and Technology A, Vol. 5 : 146-152.

Brunet, J., P. Bernard, R. Maude, L.J. Philippe, W.P. Alexander, A.B. Ahmed, Y. Helene, F. Emilie, D.C. Jean, M.E. Gema, G.M. Magdalena, M.S. Joaquina and C. Ermanno. 2017. Molecular Diagnosis of Pseudoterranova decipiens in human, France. BMC Infectious Diseases, Vol. 17(397): 1-5.

Bucci, C., Gallotta, S., Morra, I., Fortunato, A., Ciacci, C., \& Iovino, P. 2013. Anisakis, just think about it in an emergency.
International Journal of Infectious Diseases, Vol. 17(11): 10711072.

Buchmann, K., \& Mehrdana, F. 2016. Effects of anisakid nematodes Anisakis simplex (sl), Pseudoterranova decipiens (sl) and Contracaecum osculatum (sl) on fish and consumer health. Food and Waterborne Parasitology, Vol. 4: 13-22.

Campbell, N. A. \& J. B. Reece. 2010. Biologi, Edisi Kedelapan Jilid 3 Terjemahan: Damaring Tyas Wulandari. Jakarta: Erlangga, 456 hal.

Castellanos, J., Mercado, R., Pena, S., Pustovrh, M.C., Salazar, L. 2020. Anisakis physeteris y Pseudoterranova decipiens en el pez Mugil curema comercializado en Tumaco, Colombia. Revista MVZ Cordoba, Vol. 25 (2) : e1781.

Cipriani, P., Acerra, V., Bellisario, B., Sbaraglia, G.L., Cheleschi, R., Nascetti, G., Mattiucci, S. 2016. Larval migration of the zoonotic parasite Anisakis pegreffi (Nematoda : Anisakidae) in European anchovy, Engraulis encrasicolus : Implications to seafood safety. Food Control, Vol. 59 : 148-157.

Diba, D. F. 2009. Prevalensi dan Intensitas Infestasi Endoparasit Berdasarkan Hasil Analisis Feses Kura-kura Air Tawar (Coura amboinensis) di Perairan Sulawesi Selatan. Tesis. Sekolah Pascasarjana. Institut Pertanian Bogor. Bogor. 47 hal

Ghazali, T.M., Firmansyah, R., Sibuea, N.U.S., Bagariang, R. I., Matondang, S. R. 2020. Identification and Prevalention of Parasite in Big eye scad (Selar crumenophthalmus) on Fish Auction in Sibolga. Jurnal Perikanan dan Kelautan, Vol. 25(2): 158-162.

Guan, A., I.V. Damme, F. Devlieghere, S. Gabriel. 2021. Effect of temperature, $\mathrm{CO}_{2}$ and $\mathrm{O}_{2}$ on motility and mobility of Anisakidae larvae. Scientific Reports, Vol. 11 : 4279.

Gunarto, L. 2006. Parasit Metazoan pada Ikan Tenggiri, Scomberomorus commerson (Lacepede, 1800) di perairan Sulawesi. Tesis. Sekolah Pascasarjana Institut Pertanian Bogor, 116 hal.

Hafid, M. D \& Anshary, H. 2016. Keberadaan Anisakis typica (Anisakidae) dari Ikan Tongkol dan Ikan Layang dari perairan Sulawesi Barat. Jurnal Sain Veteriner, Vol. 34(1): 102-111.

Handayani, I.P. 2019. Ko-infeksi Anisakidae dengan Berbagai Parasit pada Ikan Kerapu (Epinephelus sp.) di Tempat Pelelangan Ikan Weru Paciran Lamongan. Tesis. Universitas Airlangga.

Herman, M., Gunanti, M., dan Sri, S. 2013. Identifikasi dan Prevalensi Cacing pada Saluran Pencernaan Ikan Kembung (Rastrelliger brachysoma) di Pelabuhan Perikanan Nusantara Brondong, Lamongan. Journal of Aquaculture and Fish Health, Vol. 3(1): 13-19.

Hibur, O, S. Detha, A, I dan Irmasuryani. 2016. Tingkat Kejadian Parasit Anisakis sp. Pada Ikan Cakalang dan Ikan Tongkol yang Dijual di Tempat Penjualan Ikan Pasir Panjang Kota Kupang. Jurnal Kajian Veteriner, Vol. 4 (2): 40-51.

Hoshani, N.A., Quraishy, S.A., Dkhil, M.A., Baiomy, A.A., Gaber, R.A. 2020. First record of third-stage Terranova larval type II (Nematoda, Anisakidae) in the common ponyfish Leigonathus equulus Forsskal. Microbial Pathogenesis. Vol. 149.

Hossen, M. S., \& Shamsi, S. 2019. Zoonotic nematode parasites infecting selected edible fish in New South Wales, Australia. International Journal of Food Microbiology, Vol. 308: 108306.

Hutama, F.P., Kismiyati., Mahasri, G., Wulansari, P.D. 2018. Identifikasi and prevalensi cacing endoparasit pada Ikan 
Layang Deles (Decapterus macrosoma) di Pelabuhan Perikanan Nusantara Brondong, Lamongan. Jurnal Akuakultur Rawa Indonesia, Vol. 6(1): 77- 82.

Indaryanto, F, R., Yusli, W dan Risa, T. 2014. Struktur komunitas cacing parasitik pada Ikan Kembung (Rastrelliger Spp.) di Perairan Teluk Banten dan Pelabuhan Ratu. Jurnal Ilmu Pertanian Indonesia, Vol. 19(1): 1-8.

Ishikura, H., Kikuchi, K., Nagasawa, K., Ooiwa, T., Takamiya, H., Sato, N. and Sugane, K. 1993. Anisakidae and anisakidosis. In Progress in clinical parasitology, Vol. 43-102.

Ivanovic, J., Baltic, M.Z., Boskovic, M., Kilibarda, N., Dokmanovic, M., Markovic, R., Janjic, J., Baltic, B. 2017. Anisakis allergy in human. Trends in Food Science and Technology, Vol. 59: 25-29.

Kementerian Kelautan dan Perikanan. 2018. Laporan Tahunan 2018. 120 hal.

Kuhn, T., Cunze, S., Kochmann, J., Klimpel, S. 2016. Environmental variables and definitive host distribution: a habitat suitability modelling for endohelminth parasites in the marine realm. Scientific reports, Vol. 6(1): 1-14.

Kushadiwijayanto, A. A., Ningsih, N. S., \& Al Azhar, M. 2019. Analisis sensitifitas model pasang surut di Laut Indonesia bagian timur menggunakan ROMS_Agrif. Jurnal Fisika Flux: Jurnal Ilmiah Fisika FMIPA Universitas Lambung Mangkurat, Vol. 16(2); 69-77.

Knoff, M., Fonseca, M.C.G., Felizardo, N.N., Santos, A.L., Clemente, S.C.S., Kohn, A., Gomes, D.C. 2017. Anisakidae and Raphidascarididae nematodes parasites of Tuna (Perciformes : Scombridae) from State of Rio de Janeiro, Brazil. Neotropical Helminthology, Vol. 11(1) : 45-52.

Koinari M, Karl S., Elliot, A., Ryan, U., Lymbery, A.J. 2013. Identification of Anisakis species (Nematoda: Anisakidae) in marine fish hosts from Papua New Guinea. Veterinary Parasitology, Vol. 193(1-3): 126-133.

Łopieńska-Biernat, E., R. Stryiński, M. Dmitryjuk, B., Wasilewska. 2019. Infective larvae of Anisakis simplex (Nematoda) accumulate trehalose and glycogen in response to starvation and temperature stress. Biology Open, Vol. 8 : bio040014.

Liananda, F.D.F., Kismiyati, K., Mahasri, G., Sari, P.D.W. 2017. Identifikasi dan prevalensi cacing endoparasit pada Ikan Swanggi (Priacanthus macracanthus) di Pelabuhan Perikanan Nusantara Brondong, Lamongan. Journal of Aquaculture and Fish Health, Vol. 6(3): 107-114.

Lima, F., Pozza, A., Lehmann, P. 2019. Contracaecum spp. (Nematoda : Anisakidae) and Eustrongylides spp. (Nematoda : Dioctophymatidae) Nematoda larvae with zoonotic potential found in two fish species from Tramandai River Basin, Southern Brazil. Boletim Do Instituto De Pesca, Vol. 45(3) : 3495.

Linayati, L., \& Madusari, B.D. 2019. Prevalence and distribution of Anisakis sp worms in internal organs of Tuna (Euthynnus affinis) at fish auction in Pekalongan City. IOP Conference Series : Earth and Environmental Science 399 : 012109.

Mantra. I. 2008. Filsafat Penelitian dan Metode Penelitian Sosial Yogyakarta: Pustaka Pelajar, 155 hal.

Mattiucci, S., Cipriani, P., Webb, S. C., Paoletti, M., Marcer, F., Bellisari, B., Gibson, D. I. and Nascetti, G. 2014. Geneticand morphological approaches distinguish the three sibling species of the Anisakis simplex species complex, with a species designation as Anisakis berlandi n. sp. for A simplex sp. C (Nematoda: Anisakidae). Journal Parasitology, Vol. 100(2): 199-214.
Mattiucci, S. \& Nascetti, G. 2006. Molecular systematics, phylogeny and ecology of Anisakid Nematodes of the genus Anisakis Dujardin, 1845: an update. Parasite, Vol. 13: 99-113.

Measures, L.N. 2014. Anisakiosis and Pseudoterranovosis. U.S. Geological Survey, Reston, Virginia, 129 hal.

Mehrdana, F. \& K. Buchmann. 2017. Excretory/secretory products of anisakid nematodes : Biological and pathological roles. Acta Veterinaria Scandinavica, Vol. 59 (42) : 1-12

Meirinawati, H., \& Iskandar, M. R. 2019. Karakteristik fisika dan kimia perairan di Laut Jawa-Ambang Dewakang. Oseanologi dan Limnologi Di Indonesia, Vol. 4(1); 41-52.

Murata, Y., Ando, K., Usui, M., Sugiyama, H., Hayashi, A., Tanemura, A., Kato, H., Kuriyama, N., Kishiwada, M., Mizuno, S., Sakurai, H., Isaji, S. 2018. A case of hepatic anisakiasis caused by Pseudoterranova decipiens mimicking metastatic liver cancer. BMC Infectious Disease, Vol. 18 : 619.

Muttaqin, M.Z., Mazida, A., Aminin. 2021. Catatan pertama infeksi Anisakid (Nematoda) pada Ikan Kakap Merah (Lutjanus malabaricus) dan Kerapu (Epinephelus sexfasciatus) di Kabupaten Gresik, Indonesia. Jurnal Perikanan Pantura, Vol. $4(1): 1-8$

Palm, H.W., Theisen, S., Damriyasa, I.M., Kusmintarsih, E.S., Oka, I.B.M., Setyowati, E.A., Suratma, N.A., Wibowo, S., Kleinertz, S. 2017. Anisakis (Nematoda: Ascaridoidea) from Indonesia. Diseases of Aquatic Organisms, Vol. 123: 141- 157.

Pekmezci, G.Z., Onuk, E. E., Bolukbas, C. S., Yardimci, B., Gurler, A. T., Acici, M., Umur, S. 2014. Molecular identication of Anisakis species (Nematoda: Anisakidae) from marine shes collected in Turkish waters. Veterinary Parasitology, Vol. 201: 82-94.

Piras, M. C., Tedde, T., Garippa, G., Virgilio, S., Sanna, D., Farjallah, S., Merella, P. 2014. Molecular and epidemiological data on Anisakis spp. (Nematoda: Anisakidae) in commercial fish caught off northern Sardinia (western Mediterranean Sea). Veterinary Parasitology, Vol. 203(1-2): 237-240.

Pozio, E. 2013. Integrating animal health surveillance and food safety: the example of Anisakis. Scientific and Technical Review of the Office International des Epizooties, Vol. 3(2): 487-496.

Pradipta, R., Sri, S \& Kismiyati. 2015. Identifikasi dan prevalensi cacing pada saluran pencernaan Ikan Salem (Scomber japonicus) di Pangkalan Pendaratan Ikan Muara Angke, Jakarta Utara. Jurnal Ilmiah Perikanan dan Kelautan, Vol. 7(1): 109114.

Puspitarini, D.A., S. Subekti \& Kismiyati. 2018. Identifikasi dan prevalensi cacing endoparasit pada saluran pencernaan Kakap Merah (Lutjanus argentimaculatus) di Keramba Jaring Apung Balai Besar Perikanan Budidaya Laut, Lampung. Jurnal Ilmiah Perikanan dan Kelautan, Vol. 10(1): 59-64.

Quraishy, S.A., Abdel-Gaber, R., Dkhil, M.A.M. 2019. First record of Pseudoterranova decipiens (Nematoda, Anisakidae) infecting the Red spot emperor Lethrinus lentjan in The Red Sea. Brazilian Journal of Veterinary Parasitology, Vol. 28 : 4.

Raharjo, H.M., Koesdarto, S., Sumarsono, Q.C.K.N., Permatasari, F.D., Wastomi, Z.N., Sari, N.S.A. 2018. Anisakidae as a bioindicator candidate in response to environmental damage. Advances in Social Science, Education and Humanities Research, Vol. 98 : 374-376.

Rahmi, H., R. 2020. Identifikasi Anisakidae Pada Ikan Kakap Merah (Lutjanus Malabaricus) Di Perairan Jawa Timur. Doctoral dissertation, Universitas Airlangga, 65 hal. 
Rodríguez, N.E.R., Sánchez, V.V., Anda, F.R.G.D., Reyna, P.B.G., Rosa, L.G.D.L. and Zepeda-Velázquez, A.P., 2020. Species of Anisakidae nematodes and Clinostomum spp. infecting lisa Mugil curema (Mugilidae) intended for human consumption in Mexico. Brazilian Journal of Veterinary Parasitology, Vol. 29(1): 1-8.

Shamsi, S. \& Suthar, J. 2016. Occurance of Terranova larval types (Nematoda : Anisakidae) in Australian marine fish with comments on their spesific identitites. PeerJ, Vol. 4 : e1722.

Siagian, F.E. \& Maryanti, E. 2020. Anisakiasis pada ikan laut di Indonesia : prevalensi, sebaran dan potensi patogenitasnya pada manusia. Jurnal Ilmu Kedokteran, Vol. 14 (1) : 8-20.

Smith, J. W., \& Wootten, R. 1978. Anisakis and anisakiasis. In Advances in parasitology, Vol. 16: 93-163.

Sohn, W.M., Kang, J.M. \& Na, B.K., 2014. Molecular analysis of Anisakis type I larvae in marine fish from three different sea areas in Korea. The Korean journal of parasitology, Vol. 52(4): 383.

Susilo, E., Islamy, F., Saputra, A. J., Hidayat, J. J., Zaky, A. R., \& Suniada, K. I. 2015. Pengaruh Dinamika Oseanografi Terhadap Hasil Tangkapan Ikan Pelagis PPN Kejawanan dari Data Satelit Oseanografi. In Seminar Nasional Perikanan dan Kelautan V. Universitas Brawijaya, 299-304.

Tafonao, B. 2011. Hubungan Temperatur, Oksigen Terlarut dan Salinitas dengan Prevalensi Parasit pada Ikan Kerapu Lumpur (Epinephelus tauvina). Skripsi. Fakultas Perikanan. Universitas Dharmawangsa. Medan, 57 hal.

Toyoda, H., \& Tanaka, K. 2016. Intestinal anisakiasis treated successfully with prednisolone and olopatadine hydrochloride. Case reports in gastroenterology, Vol. 10(1): 3035 .

Utami, P., Handayani, N.S.N. \& Kunda, R.M. 2017. Identification of genetic diversity Cytochrome Oxidase Subunit II (COII) mitochondrial gene as genetic marker for Anisakis species in Euthynnus affinis. Jurnal Kedokteran Hewan, Vol. 11(4): 118124.

Vega, I., Molina-Fernández, D., Benítez, R., Hernández-Trujillo, S. and Adroher, F.J. 2017. Early development and life cycle of Contracaecum multipapillatum sl from a brown pelican Pelecanus occidentalis in the Gulf of California, Mexico. Diseases of aquatic organisms, Vol. 125(3): 167-178.

Weitzel, T., Sugiyama, H., Yamasaki, H., Ramirez, C., Rosas, R., Mercado, R. 2015. Human infections with Pseudoterranova cattani nematodes, Chile. Emerging infectious diseases, Vol. 21(10): 1874-1875.

Yorimitsu, N., Hiraoka, A., Utsunomiya, H., Imai, Y., Tatsukawa, H., Tazuya, N., Hasebe, A. 2013. Colonic intussusception caused by anisakiasis: a case report and review of the literature. Internal Medicine, Vol. 52(2): 223-226.

Yusron, E. 2012. Biodiversitas jenis Cetacean di Perairan Lamalera, Kupang, Nusa Tenggara Timur. Indonesian Journal of Marine Sciences/Ilmu Kelautan, Vol. 17(2); 59-62.

Zając, E., Różycki, M., Chmurzyńska, E., Karamon, J., Sroka, J., Kochanowski, M., Kusyk, P., Cencek, T. 2015. Parasites of Anisakidae family-Geographical distribution and threat to human health. Journal of Agricultural Science and Technology, Vol. 5: 146-152. 